\title{
K-Means Color Segmentation and Morphological Feature Extraction of Bamboo Fiber as an Environmentally Friendly Material for Soil Strengthening
}

\author{
Khoiriya Latifah $^{1 *}$, Joko Siswanto ${ }^{2}$, and Bambang Supriyadi ${ }^{3}$ \\ ${ }^{1,3}$ Engineering and Informatics Department, Universitas PGRI Semarang, Jl. Sidodadi-Timur No.24 \\ Semarang, Central Java 50232, Indonesia \\ ${ }^{2}$ Physics Department, Universitas PGRI Semarang, Jl. Sidodadi-Timur No.24 Semarang, Central Java \\ 50232, Indonesia \\ * corresponding author: khoiriyalatifah@upgris.ac.id
}

(Received: Oktober 25 $5^{\text {th }}, 2019$; Revised: March 21 $1^{\text {st }}, 2020$; Accepted: March $23^{\text {rd }}, 2020$ )

\begin{abstract}
Indonesia is one of the bamboo producing countries. One of the characteristics of good bamboo is that bamboo has a good fiber content as well. Characteristics of a good bamboo fiber is fiber that has a size and length of fiber that is large and long because it will affect the compressive strength and tensile strength of the bamboo. This study uses the K-Means color segmentation method and shape measurements based on the morphological characteristics of bamboo fibers, namely the area, circumference / perimeter and fiber roundness ratio. The results of testing with 18 images of bamboo type training show that Wulung bamboo fiber which is still of the same genus with bamboo Gombong has the largest size fiber of 40.4, the longest perimeter of 3.73 and has a roundness ratio of 0.83 bamboo Ori which has an area of 21,6 , perimeter of 3.23 and a roundness ratio of 0.79 . Bambu Petung has an area of 20.6, perimeter of 2.53 and roundness ratio of 0.79 . Java Bamboo has an area of 20.2, perimeter of 1.19 and a roundness ratio of 0.8 . Whereas Bambu Apus only has an area of 19.2, a perimeter of 2.09 and a roundness ratio of 0.78 . Testing using 8 testing images obtained an accuracy rate of 0,625 .
\end{abstract}

Keywords: morphological; K-Means; bamboo fiber; environmentally friendly; material

\section{Introduction}

Bamboo fiber is one of the natural fibers that is environmentally friendly material [1] so that bamboo fiber has many benefits. Both in the craft industry, textile and construction industry. Good bamboo will have good fiber. The characteristics of good bamboo fiber will have good tensile strength and compressive strength that it is very useful for construction materials, one of which is a good material for soil reinforcement because it has good tensile strength and compressive strength. Bamboo fiber is contained in bamboo stems as one of the constituents of the bamboo trunk that is connected by adhesive fibers in the bamboo trunk. Bamboo species are plants that are easy to grow and are found in cold regions and in the tropics. Indonesia is a tropical country so Indonesia is one of the biggest bamboo producing countries in the world. Various types of bamboo that can flourish in Indonesia, so we must be able to distinguish the types of bamboo that have good fiber quality because good bamboo will produce bamboo fiber with good quality. There are many ways to distinguish the quality of bamboo fiber. One effective and cheaper way is use the digital image processing applications. Digital image processing is able to identify the number of objects in an image by using feature extraction [2]. Feature extraction is the process of 
capturing the characteristics and values of an object in an image. The value obtained from the feature extraction process is used to conduct training (training) to recognize the input object. Feature extraction of an object in an image can be in the form of texture, color and shape extraction [3]. In this study the authors analyzed the image using feature form extraction including size to determine the quality of bamboo fibers because according to laboratory results good quality fiber has morphological characteristics that are large and long fibers because they contain many substances in these fibers that affect the strength and quality of these fibers [4]. The shape of an object is related to the physical structure and profile of the object. Shape is a physical form characteristic [5] a bamboo fiber which is usually referred to as the morphological characteristic of a bamboo fiber that distinguishes bamboo from one another. Shape measurement parameters used to determine the shape of bamboo fiber in this study uses a roundness ratio that is to determine the roundness ratio of an object. As for measuring objects using the area and perimeter parameters [6]. Area is the number of pixels that make up an object. While the perimeter (perimeter) is the number of pixels surrounding an object or skeleton produced. With eccentricity parameters, area and perimeter, the shape and size of [7] bamboo fiber will be known how big the bamboo fiber is so that we are able to distinguish one large bamboo fiber from another bamboo fiber. Because the amount of fiber in the stems of each bamboo stem that has a different type will also have different sizes so that we can distinguish the quality of good bamboo fibers between several types of bamboo that grow around us.

\section{Research Methods}

\subsection{Sampling of Research}

This study uses 5 types of bamboo that are often used in the Semarang and surrounding areas. Bamboo that grows in Semarang and its surrounding areas, among others, is Duri / Ori bamboo, Wulung bamboo, Petung bamboo, Javanese / Legi / Temen bamboo, Apus / Tali bamboo. Bamboo Petung and Wulung are bamboo which have the same clumps as bamboo Gombong.

\subsection{Image capturing}

Image capturing was conducted using a Canon 60D digital camera. Capturing the image is done when the weather is sunny, in the morning at 10:00 WIB using a tripod to avoid shaking when shooting. The distance between the image and object is $20 \mathrm{~cm}$. The capturing object is obtained by cutting each type of bamboo at the base of the bamboo which all bamboo ages are 3 years. Samples were obtained from 25 bamboo culms of all types of bamboo. The bamboo base of the base tends to be easily photographed so the research sample uses the stem base.

\subsection{Image segmentation}

Image segmentation is the process of separating image fibers from fiber adhesives. Segmentation is an important step [8] to separate the research object from other objects. Segmentation is an important stage in analysis because the results of segmentation will determine the interpretation of the image. This study uses K-Means color segmentation. The color group used is HSV color because HSV is a color that approaches color perception according to human eye perception and distance measurement using Euclidean Distance. Cluster-based segmentation is by clustering pixels based on the distance between pixels so that the success of cluster-based segmentation is determined by the success in grouping adjacent features into one cluster. The segmentation used is multidimensional data cluster-based segmentation to group pixel images into several clusters in this study using K-Means because K-Means is an adaptive and more flexible segmentation method [9]. 


\subsection{Image analysis}

After the segmentation is done, to interpret the image of the results of segmentation the author uses the extraction of the shape and size of the object with the roundness and circumference ratio parameters of the object and the area to find the magnitude of the fibers in the bamboo stems. Feature extraction is the process of taking the characteristics and values of an object in an image. The values obtained from the feature extraction process will be used to conduct training (training) to recognize the input object [10].

\section{Result and Discussion}

\subsection{K-Means Clustering Segmentation}

This study uses 25 images of each type of bamboo. The bamboo chosen as a sample is bamboo that grows a lot in the Semarang area and bamboo which is often used for the construction industry in Semarang includes Duri / Ori bamboo, Wulung bamboo, Petung bamboo, Javanese / Legi / Temen bamboo, Apus / Tali bamboo. Bamboo Petung and Wulung are bamboo which have the same clump as bamboo Gombong. The image is divided into 2 images as much as $60 \%$ training (18 images) and 40\% (7 images) are testing images of each type of bamboo. Segmentation is used to separate the fiber from the fiber adhesive in the bamboo culm. K-Means groups objects into 2 clusters, namely fiber and fiber adhesive. After dividing into 2 clusters, K-Means will search for cluster centers and cluster boundaries through an iterative process. Proximity between one object with another object is measured using the Euclidean distance method. The iteration method of KMeans with $\mathrm{K}=2$ starts by choosing a random threshold as an initial value, then the value is corrected based on the distribution of the image intensity values.

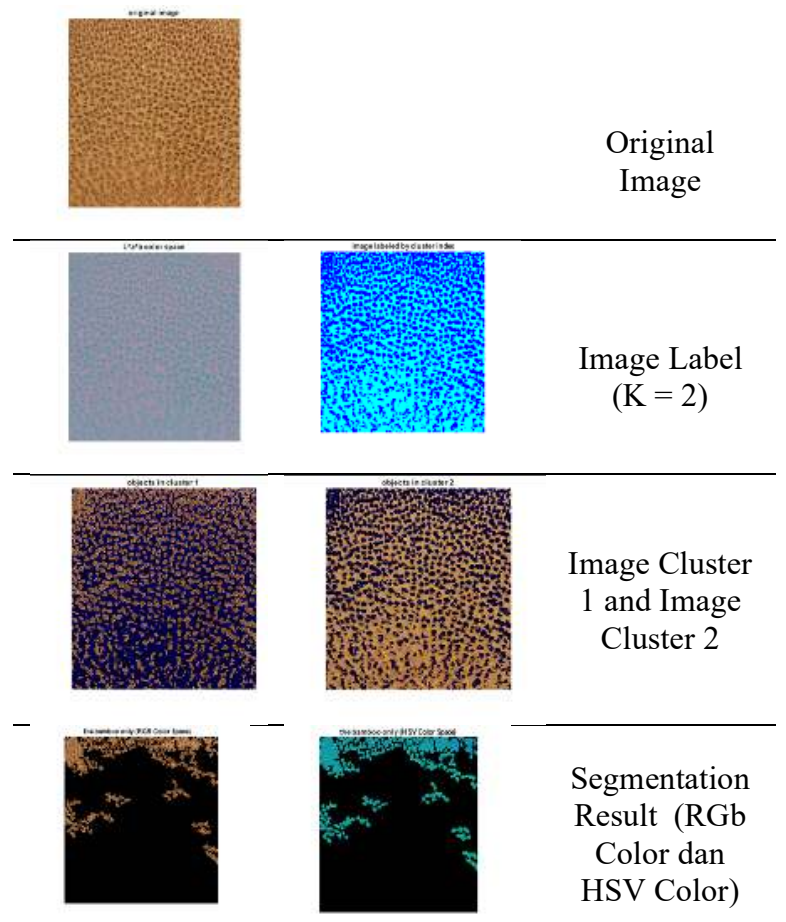

Fig. 1. Image Source and Image Segmentation Results Using K-Means Color Segmentation

Apply K-Means Clustering Algorithm

a. Choose a fixed number of clusters

b. Choose cluster centers and point-cluster allocations to minimize errors 
c. Apply Connected Components Algorithm, Merge any components of size less than to an adjacent component that is most similar to it. After getting the new $\mathrm{k}$ group, the distance calculation uses Euclidean for all data to the nearest centroid until there is no change in the center of the cluster.

\subsection{Extraction of shape and size characteristics}

Image analysis in this study uses the geometrical properties of objects as characteristics of objects in the image. This study uses the characteristics of the area, perimeter and roundness ratio because the measurement of the quality of the fiber is determined by the geometry of how much fiber from each type of bamboo from the segmented image. The area is the number of pixels that make up the object (bamboo fiber). The area reflects the size of the object as much as possible. While the Perimeter is the length of the boundary of the object (bamboo fiber) with fiber adhesive. Perimeter size is measured by counting the number of pixels of the object boundary. Objects in image f have a consistent value and background value of 0 . Thus the morphological features of bamboo fibers can be determined by calculating how wide the pixel area of the constituent bamboo fibers is and how long the border of the bamboo fibers is in the image resulting from the segmentation. After knowing the area, perimeter then to find out the compactness of an object (bamboo fiber) is measured through the dimensionless form factor with the formula

$$
C=\frac{P^{2}}{A}
$$

Where :

$$
\begin{array}{ll}
\mathrm{C} & \text { : compactness } \\
\mathrm{P} & \text { : Perimeter } \\
\mathrm{A} & : \text { Area }
\end{array}
$$

Compactness is used to identify the same shape and size but with different object edge profiles. Roundness or $\mathrm{R}=4 \pi \mathrm{A} / \mathrm{P}^{2}$. The roundness factor is used to classify the shape of objects that are connected with the round and elongated shapes. Bamboo fiber is an object that is shaped like a circle so the ratio value is close to 1 while for objects whose roundness ratio value is close to 0 , the object is square or square.

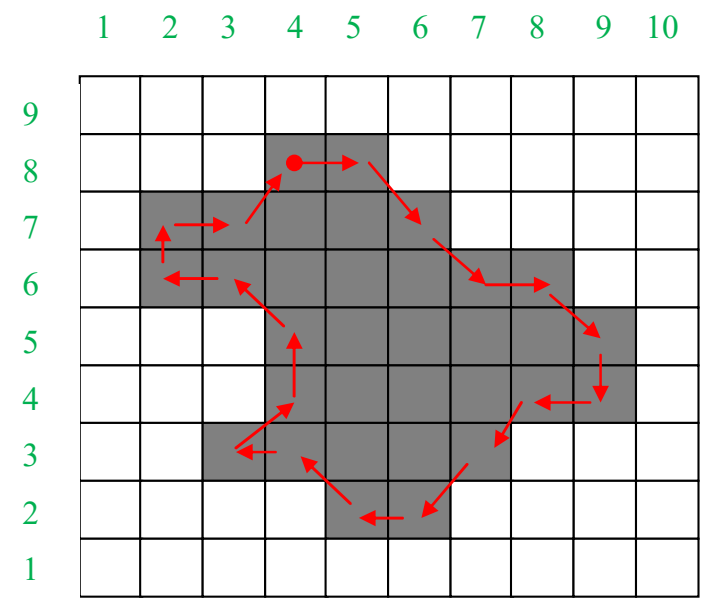

Fig. 2. Area and Perimeter

Caption : Gray is the area and the red line is the Perimeter / Surrounding Object

From the results of the training image calculation, the average results are as follows : 
Table 1. Morphological Characteristics of Bamboo

\begin{tabular}{lccc}
\hline \multicolumn{1}{c}{ Type of Bamboo } & Area Size & Perimeter & Roundness Ratio \\
\hline Bambu Ori / Duri & 21,6 & 3,23 & 0,79 \\
\hline Bambu Jawa / Legi & 20,2 & 1,19 & 0,80 \\
\hline Bambu Wulung & 40,4 & 3,74 & 0,83 \\
\hline Bambu Petung & 20,6 & 2,53 & 0,79 \\
\hline Bambu Apus & 19,2 & 2,09 & 0,78 \\
\hline
\end{tabular}

Based on 18 images of bamboo type training ( $60 \%$ of training data) obtained above data that bamboo Wulung is bamboo which is allied with bamboo Gombong which has the largest area of 40.4 , perimeter (circumference) the longest of 3.73 and has roundness ratio of 0.83 . This is in accordance with the results of the fiber laboratory that the Bamboo Wulung which is still in close alliance with bamboo Gombong has the best fiber quality because it has a large fiber size, then followed by bamboo Ori which has an area of 21,6 , perimeter of 3.23 and a roundness ratio amounted to 0.79. While Petung Bambu is ranked no. 3 because it has an area of 20.6, perimeter of 2.53 and roundness ratio of 0.79 . Java Bamboo is ranked 4th because it only has an area of 20.2 , a perimeter of 1.19 and a roundness ratio of 0.8 . While Bambu Apus is ranked 5th because it only has an area of 19.2, perimeter of 2.09 and roundness ratio of 0.78 . From the results of the above calculation there are still many shortcomings because they still cannot parse one by one the fibers that are in the image of segmentation results. Training data was tested using 8 image testing $(40 \%)$ bamboo test types and obtained. Accuracy generated by classification training with the area ratio and perimeter parameters is:

$$
\begin{aligned}
& \text { Accuracy }=\frac{\text { number of right identified data }}{\text { number of identified data }} \times 100 \% \\
& \text { Acuracy }=\frac{25}{40} \times 100 \%=0.625
\end{aligned}
$$

\section{Conclusion}

This study uses clustering-based segmentation method using K-Means color segmentation where $\mathrm{K}=2$ by looking for the morphological characteristics of bamboo images based on area, perimeter and roundness ratio results show that bamboo Wulung is the best bamboo because it has the largest fiber and the image analysis results are in accordance with the results of the fiber laboratory analysis. An accuracy rate of $50 \%$ so to get a better level of accuracy the research that will be dating needs to use other segmentation methods with identification using another pattern recognition algorithm. So it can be concluded that bamboo Wulung is a good bamboo because it has fiber with a large size and high fiber length so it is good to be used as a soil strengthening material in Semarang that has subsidence.

\section{Acknowledgments}

We would like to thank the Directorate of Research and Community Service, Directorate General of Research and Technology Strengthening from the Ministry of Research, Technology, and Higher Education for funding this research through the "Primary Educational Excellence Research (PDUPT) 2017-2019" scheme.

\section{References}


[1] Frick, H., 2004, Ilmu konstruksi bangunan bambu-Pengantar konstruksi bambu, Yogyakarta: Kanisius.

[2]. E. Prasetyo, Pengolahan Citra Digital dan Aplikasinya Menggunakan Matlab. 2011, Yogyakarta: Andi Offset.

[3] Kebapci, Hanife, et all," "Plant Image Retrieval Using Color, Shape and Texture Features." The Computer Journal Advance Access published April 9, 2010.

[4] Latifah, Supriyadi, Rochim "Characteristics of Bamboo Fiber as Environmentally Friendly Material for Soil Strengthening," 1st International Conference on Education and Social Science Research, Universitas PGRI Semarang, 2013, Atlantis Press, Advances in Social Science, Education and Humanities Research vol. 287, hal. 18-21, 2019.

[5]. R. Alzu, "Medical Image Segmentation via Optimized K-Means," International Conference on Current Trends in Computer, Electrical, Electronics and Communication (ICCTCEEC-2017) hal. 959-962, 2017.

[6] Gnanapriya S et all, "Identification Of Organics Fruits Using Color and Size Features" 2017 IEEE International Conference On Technological Innovation in ICT For Agriculture and Rural Development (TIAR 2017).

[7] A. Bhan, D. Sharma, dan S. Mishra, "Computer Based Automatic Segmentation of Pap smear Cells for Cervical Cancer Detection," 2018 5th Int. Conf. Signal Process. Integr. Networks, SPIN 2018, hal. 883-887, 2018.

[8]. Pamungkas Adi, 2015, Identification of Plasmodium Falciparum Development Phase in Malaria Infected Red Blood Cells using Adaptive Color Segmentation and Decision Tree based Classification, International Journal of Applied Engineering Research ISSN 09734562 Volume 10, Number 2 , pp. 4043-4055.

[9]. Putra, D., 2009, Pengolahan Citra Digital, Penerbit Andi, Yogyakarta.

[10] A . Acharya, T.; Ray, Image Processing Principles and Applicationso Title. New Jersey: John Wiley \& Sons, Inc. 2005. 